\title{
Martha's Diary and Mine
}

\section{Citation}

Ulrich, Laurel Thatcher. 1992. "Martha's Diary and Mine." Journal of Women's History 4 (2): 157160.

\section{Published Version}

doi:10.1353/jowh.2010.0144

\section{Permanent link}

http://nrs.harvard.edu/urn-3:HUL.InstRepos:14123820

\section{Terms of Use}

This article was downloaded from Harvard University's DASH repository, and is made available under the terms and conditions applicable to Other Posted Material, as set forth at http:// nrs.harvard.edu/urn-3:HUL.InstRepos:dash.current.terms-of-use\#LAA

\section{Share Your Story}

The Harvard community has made this article openly available.

Please share how this access benefits you. Submit a story.

Accessibility 


\section{PROJECT MUSE}

\section{Martha's Diary and Mine}

Laurel Thatcher Ulrich

Journal of Women's History, Volume 4, Number 2, Fall 1992, pp. 157-160

(Article)

Published by The Johns Hopkins University Press

DOI: 10.1353/jowh.2010.0144

$\Rightarrow$ For additional information about this article

http://muse.jhu.edu/journals/jowh/summary/v004/4.2.ulrich.html 


\section{DOCUMENT:}

\section{Martha's Diary and Mine}

\section{Laurel Thatcher Ulrich}

TThe following essay was my acceptance speech at the Bancroft Prize award 1 dinner, Columbia University, April 3, 1991. Since the award ceremony follows a sumptuous dinner, prize winners are encouraged to save their sophisticated historiographic insights for another occasion and "be personal." This is what I said:

I spent eight years studying the diary of Martha Moore Ballard, an eighteenth-century Maine midwife. As I was thinking about how I could explain that to you, I remembered my own diary. It is a pretty miserable affair compared to Martha's-four ruled notebooks with intermittent entries scattered over fifteen years, but when I went back to read what I had written I was surprised to discover how much it told me about my life with Martha.

My diary entry for April 18, 1982, seems particularly fitting for a Bancroft Acceptance Speech. "The summer should be interesting," I began, adding that, my husband Gael, was going to be a full-time parent and househusband in July and August because I had "an NEH Summer fellowship to work on Martha Ballard's diary." Then I went on to comment on the recent publication of my first book. "Good Wives is out. Except for a short review in the NY Times, silence. Sort of an eery feeling ... I like Good Wives a lot. Mother likes it. Gael likes it. And [our neighbor] Parker Ayer finds it worth reading. . . . I suppose I am a ways from celestial values. I crave the validation of gushing reviews. A Bancroft Prize would be nice, too." I honestly have no recollection of ever thinking such a thing, let alone writing it down. Diary keeping is a dangerous activity.

People often ask me how I found Martha Ballard's diary. The answer is "by accident." I had gone to the Maine State Archives pursuing an early court case that interested me. I ran out of documents by mid-afternoon, and since Augusta, Maine, is a long way from Durham, New Hampshire, and I did not want to waste my trip, I decided to stop in at the adjoining state library to look at two diaries I had seen in a bibliography of women's history. One turned out to be a ten-page typescript. The other was Martha's-two fat volumes bound in homemade linen covers. Because I had found so few women's documents in my research for Good Wives, I was awed by the sheer bulk of it. The faded ink was difficult to read; but in the hour or so before closing I transcribed several pages-enough to form the base for the grant application that gave me the summer fellowship. 
Reading my own journals, I was surprised at how soon into the summer research the idea for the book began to form. After a few weeks in Augusta I had arranged to have the diary microfilmed so I could continue the work in Durham. On July 17, 1982, I wrote:

As I was walking home from the UNH library yesterday I suddenly felt I should do a book on the diary. ... The trick would be to write something more accessible than the diary itself. Is this midwifery or bastardy-to borrow a metaphor from Mrs. Ballard's world? Am I giving her life to the world or substituting an "illegitimate" book for a real book-hers[?].

The key sentence is probably the next one: "This project appeals to me as a writer." Fortunately I recognized early on that I was a better storyteller than editor, that I did not have the patience or the humility to spend years transcribing a document as massive as this one. I also recognized, I think, that my experience in writing Good Wives allowed me to see things in the diary that other people might not recognize. I had no idea how difficult it would be to actually write the book. "I don't suppose the historical issues are terribly complex," I wrote, adding blithely, "This should be about [a] 150 page book-with maps and photographs."

By August, while Gael was holding things together at home, I was working full-time at the library-reading negative microfilm-white on black. No wonder I sometimes forgot where I was. My diary entry for August 5 begins:

I almost wrote 1782. I am at least ankle deep in Mrs. Ballard's Book. I have spent a full week now reading microfilm and filling out data sheets. When I came out of the library the other day, it was raining. I knew it would be because I had just been reading about it - the freshet was rising in Mrs. Ballard's world which had somehow become my own.

In September Gael and I both went back to teaching-and to sharing responsibility for our rambunctious house. Karl, Mindy, and Nathan were away at school, though they liked to show up on weekends and holidays with several friends and occasionally a big black dog. Thatcher was thirteen in 1982; Amy was seven. On February 26, 1983, I wrote:

It gets more \& more difficult to write in this journal. The semester is five weeks gone. What a wild month it has been-snow days, flu, and trying to be at school by 9 to lecture to 200 students.

I then follow with a long discussion about Nancy Chodorow's book, The Reproduction of Mothering, which our women's studies faculty had been discussing. 
Must we assume male dominance of the culture because we admit male dominance of those aspects of the culture controlled by men? Suppose we admitted for the sake of argument that motherhood was powerful. Could we find men speaking through women's language (even in imagination)? What would male culture look like if it were the muted text?

Much of my own diary is in fact about mothering, though at a practical rather than theoretical level. I was surprised, remembering those times, at how upbeat most of the entries really are; a tip-off, of course, that one should never trust a diary. Despite my good humor it is obvious that, like most working parents, Gael and I were stretched in many directions:

June 7, 1983

Saturday I was frantically finishing a review essay for Trends in History. Monday was Memorial Day. Amy marched in the parade in the rain. Gael \& I ran a game at the school fair ... chasing yellow \& green tennis balls in a downpour, kids lined up ten deep to take their chances winning a squirt gun. Tuesday \& Wednesday I wrote an NEH Grant, got it in the mail just in time to drive to Sanbornton to speak to their historical society.

That NEH grant, written in a frenzy and dropped at the Durham Post Office thirty seconds before closing, eventually gave me a full year to continue my work on Martha's diary.

Unfortunately, the grant did not provide a housekeeper and nanny. On December 22, 1984, I wrote in triumph, "I managed to write 30 pages in 10-days," then added, "I have been writing notes to myself all morning, puttering around among quiet kids with upset tummies. (Please not another virus-though I feel ungrateful after writing about diphtheria all week.)"

I made enough progress during my year's leave to feel quite confident that I could finish the book before my fiftieth birthday, which then seemed comfortably distant. The goal seemed appropriate, since Martha Ballard began her diary at the age of fifty. I do not need to elaborate the rest of the story. It is familiar to every scholar who attempts to complete a major project in the midst of the competing demands of teaching, family life, and community service. On July 22, 1985, just as my year's leave was coming to an end, I wrote: "I had nightmares all night that I was in Durham when I was supposed to be in Augusta, in Augusta when supposed to be in Durham!"

At some point in all this a 250 -year-old lady took up residence in the loft above my bedroom, alternately cheering me on and chastising me for my lax habits and flagging spirits. She crossed the Kennebec River at the 
crest of the spring freshet, waded through waist-deep snow, and climbed mountains of ice to reach her patients, and at the age of seventy-seven bent her swollen knees onto the bare back of a pesky horse to reach a woman in travail. How could I complain of my burdens? I am not sure when I began to call this paragon "Martha" rather than "Mrs. Ballard." Perhaps I grew less deferent as I began to discover the woman beneath the heroine. Yes, she too occasionally quarreled with her husband, offended her children, and indulged in self-pity.

It was also instructive to discover that even in the eighteenth century a woman could struggle with the double burden of caring for a house and family while doing productive work in her community. Responsible scholarship made me wary of identifying too closely with my subject, but when Martha wrote "some fatigud" (she probably pronounced it "fatagooed"), I knew what she meant. As my stack of notecards and computer files grew I said less and less about her in my diary, but she is certainly there in my continuing entries about the joys and trials of family life.

Amy had just lost her first tooth when I began my project; now she is taller than I am. During the years we all lived with Martha, our family celebrated high school and college graduations, two weddings, the completion of four Ph.D.s, and the birth of a grandchild. Gael started a new business, took up singing, and went gray. When my eighty-year-old mother was diagnosed with breast cancer, Martha sat with me at the hospital alternately marveling and despairing at the miracles of modern medicine. I survived my own cancer scare and a broken foot, but when I was called to six weeks' jury duty during a precious summer break, I concluded that Augusta's eighteenth-century magistrate, Judge North, was pulling strings somewhere in the Great Beyond, trying to prevent me from printing Martha's description of his trial for raping the minister's wife.

On July 12, 1988, one day after my fiftieth birthday, I wrote:

50 years old. I'm proud to have survived a half-century.... I suppose this is supposed to be a traumatic moment, but in the past five years I've reconstructed it into a beginning. Martha's diary-and therefore her historical life--began at fifty. I'd like to think this can be a beginning, too. ... Now for Jubilee resolutions. What would I like to begin on this day? Another chapter of Martha's Book.

Fortunately Martha Ballard's spirit rather than Joseph North's prevailed. The book was completed and published just before my fifty-second birthday. 